\title{
CONFIGURAÇÕES DE VENTANEIRAS TBM E VAZÃO - COMPARAÇÃO ENTRE BOF THYSSENKRUPP CSA E MODELO A FRIO*
}

\author{
Breno Totti Maia ${ }^{1}$ \\ Caio N. A. Diniz ${ }^{2}$ \\ Daniel A. G. de Carvalho 3 \\ Daniela Ladeira de Souza ${ }^{4}$ \\ José Artur Albano de Guimarães ${ }^{5}$ \\ Raissa Santos Salgado ${ }^{6}$ \\ Roberto P. Tavares ${ }^{7}$
}

\begin{abstract}
Resumo
O refino primário através dos convertedores BOF representa uma etapa fundamental na fabricação do aço. Em meio a um mercado desafiador e competitivo, estabilidade operacional e inovações são necessárias para alcançar qualidade e preços razoáveis. Com o intuito de estudar o sopro combinado através de um modelo físico, similar com convertedor da thyssenkruppCSA 330t, foi utilizada uma análise visual associada a métodos colorimétricos para mensurar a penetração do jato e a melhor configuração de ventaneiras. Com base nesses métodos, encontrou-se a distância banho-lança que reduz o tempo de mistura com menor probabilidade de slopping. A partir dos resultados obtidos no modelo a frio, os parâmetros foram recalculados para a prática industrial.
\end{abstract}

Palavras-chave: Refino primário, Sopro combinado, Modelo a frio, Slopping.

\section{TBM TUYERES ARRANGEMENTS AND FLOW - COMPARISON BETWEEN BOF THYSSENKRUPP CSA AND COLD MODEL}

\begin{abstract}
Primary steelmaking through BOF converters represents an important point in the steel production. Against a challenger and competitive Market, operational stability and innovations are necessary to reach quality and suitable prices. In order to study the combined blowing through cold physical model, in similarity with thyssenkruppCSA 330t converter, visual inspection and colorimetry methods were used to define the jet penetration and the best tuyeres configuration respectively, on the metal bath behavior. It was found a distance bath lance that decreases mix time with low slopping probability. After cold model results, parameters can be recalculated for industrial practice with good agreement.
\end{abstract}

Keywords: Primary Steelmaking, Combined Blowing, Cold Model, Slopping.

1 Sócio da ABM; Engenheiro Metalurgista e Doutor Pesquisador da LUMAR METALS, Belo Horizonte, MG, Brasil.

Engenheiro Metalurgista e Mestre da thyssenkrupp CSA, Rio de Janeiro, RJ, Brasil.

Engenheiro Metalurgista da thyssenkrupp CSA, Rio de Janeiro, RJ, Brasil.

Aluno de Graduação do Curso de Engenharia Metalúrgica da UFMG, Belo Horizonte, MG, Brasil. Aluno de Graduação do Curso de Engenharia Metalúrgica da UFMG, Belo Horizonte, MG, Brasil. Aluno de Graduação do Curso de Engenharia Metalúrgica da UFMG, Belo Horizonte, MG, Brasil

Sócio da ABM; Engenheiro Metalurgista; Professor Doutor do Departamento de Engenharia Metalúrgica da UFMG, Belo Horizonte, MG, Brasil. 


\section{INTRODUCTION}

Facing a challenging and competitive steel scenario, mills are constantly seeking improvements in the process, aiming the high quality steels production, associated with the reduction of process costs. In order to better develop production, new technologies and techniques are implanted in the industrial plant, such as the emergence of the combined blow in the BOF converter. The inert gas injection introduction from the bottom of the converter (TBM - Thyssen Blowing Metallurgy) increases the metal bath agitation, reducing zones of chemical stagnation, besides favoring the dephosphoration and reducing the iron in the slag. In this way, it is interesting to improve the study of the blow parameters, lance flow, nozzle number and torsion angle, DBL (bath-lance distance), flow rate and tuyeres arrangement. . Through physical modeling techniques, it is possible to recreate small-scale reactor models that can be operated in the laboratory, at a much lower cost than an experiment in an industrial plant, avoiding problems such as a fall in operational routine. Considering the similarity realized through the dimensionless numbers, it is possible to transpose the results obtained in the cold model (operated in laboratory) to the industrial reactor of thyssenkruppCSA, shown in Figure 1. In this project, the main objectives are the jet penetration analysis, the decarburization area measurement, verification of the jet and tuyeres influence and kinetic study of the process, during combined blow.

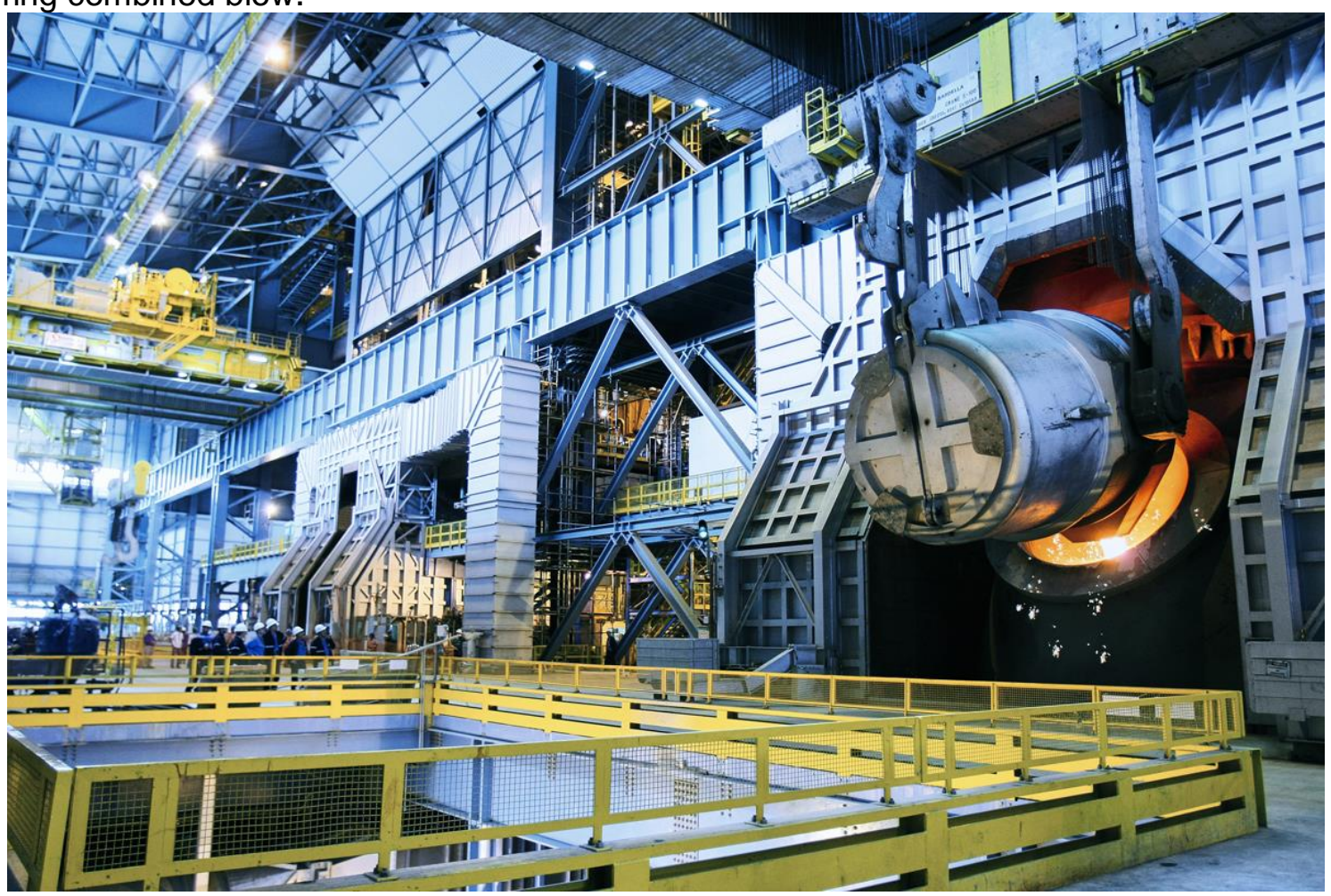

Figure 1: tkCSA converter (330 ton)

\section{MATERIALS AND METHODS}

In the LaSiP-UFMG laboratory, the experiments were carried out in a cold model of BOF converter similar to that of tkCSA with 12 air injection points in the bottom, constructed in scale 1/10. As shown in (Figure 2): 


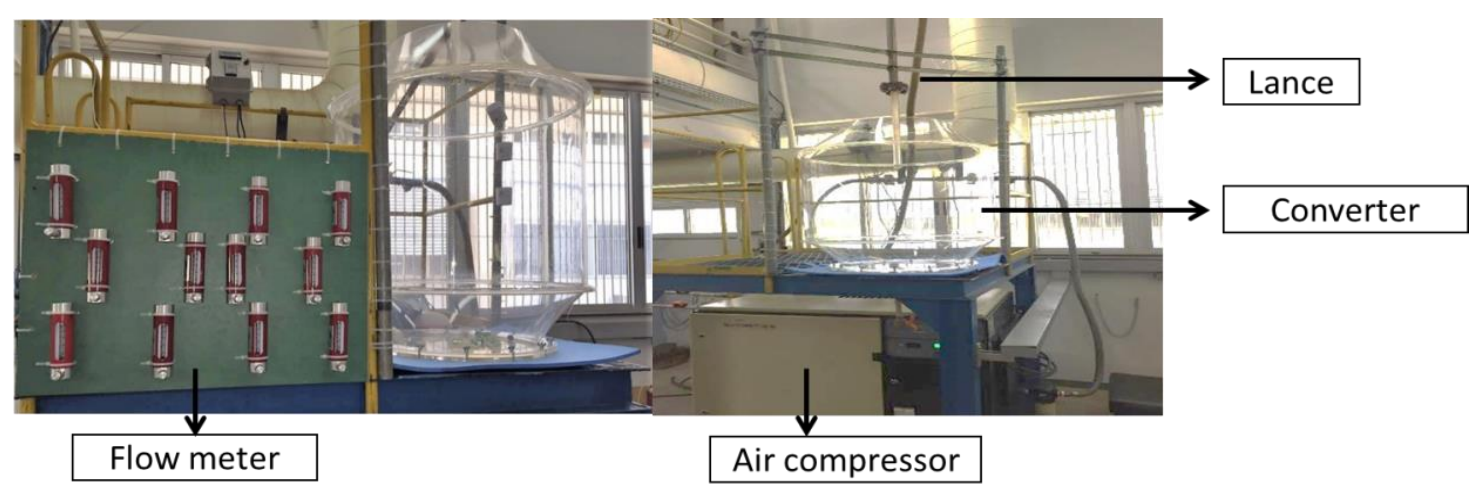

Figure 2: LaSIP structure (Process Simulation Laboratory)

The tests simulated two blowing steps performed in the tkCSA, being the decarburisation and the blowing end, as shown in Table 1.

\begin{tabular}{|c|c|c|c|c|c|c|}
\hline Blowing stage & $\begin{array}{l}\mathrm{DBL} \\
\text { tkCSA } \\
(\mathrm{m})\end{array}$ & $\begin{array}{l}\text { Table } 1 \\
\text { DBL } \\
\text { LaSiP } \\
\text { (m) }\end{array}$ & $\begin{array}{l}\text { Good blowing } \\
\text { Flow rate } \\
\text { tkCSA } \\
\text { (Nm3/min) }\end{array}$ & $\begin{array}{l}\text { lattern } \\
\text { Flow } \\
\text { rate } \\
\text { LaSiP } \\
(\mathrm{Nm} 3 / \mathrm{h})\end{array}$ & $\begin{array}{l}\text { Flow rate } \\
\text { TBM } \\
\text { tkCSA } \\
\text { (Nm3/min) }\end{array}$ & $\begin{array}{l}\text { Flow } \\
\text { rate } \\
\text { TBM } \\
\text { LaSiP } \\
\text { (NL/min) }\end{array}$ \\
\hline Decarburisation & 2.3 & 0.400 & 900 & 120 & 14 & 60 \\
\hline End of blow & 2.2 & 0.451 & 1200 & 160 & 14 & 60 \\
\hline
\end{tabular}

It is noteworthy that the laboratory flow values were determined from a conversion using the modified Froude number, expressed in the (Equation 1):

$$
F r^{*}=\frac{\rho_{\text {gas }} \times V_{\text {EXIT }}^{2} \times D_{E X I T}^{2} \times \cos \theta \times n}{\rho_{\text {STEEL }} \times g \times D B L^{3}} \quad \text { (Equation 1) }
$$

where: "Fr" - modified Froude number LASIP, relation between forces of inertia and gravitational forces., "g" - Acceleration of gravity (m.s-2), " $\rho_{\text {STEEL }}$ " - density of the bath (kg.m3), " $\rho_{\text {gas }}$ " - Gas density at nozzle outlet (kg.m-3), "VEXIT" - Speed at nozzle outlet $(\mathrm{m} / \mathrm{s})$, "DEXIT" - Nozzle outlet diameter (m/s), " $\theta$ " - Output angle with vertical, " $\mathrm{n}$ " - Number of nozzles.

It can be observed that, contrary to what happens in industrial practice, in laboratory experiments the lance rises in the final blow stage (DBL increases). This fact can be explained due to a compensation relation between the flow and the DBL.

\section{Mixing Time - Colorimetric Analysis}

Using front and lower footage, the mixing times were analyzed by the colorimetric method. This method consists in the addition of a tracer, potassium permanganate, which presents a strong coloration distinct from that presented by the bath (water), so that its mixing behavior can be observed in the bath from the moment of its addition. The gap time in which the plotter takes to reach practically the entire bath is considered the mixing time.

\section{Jet Penetration and Decarburization Area}

From the frontal filming performed for each experiment, images were obtained from three different moments of the blow, making it possible to measure, from the ImageJ® software 
(Figure 1), the jet penetration length and the decarburization area generated in the jet impact with the bath. The height of the static water bath $(200 \mathrm{~mm})$ was used as the input scale of the program, being a reference for the various possible delimitations offered by the software.

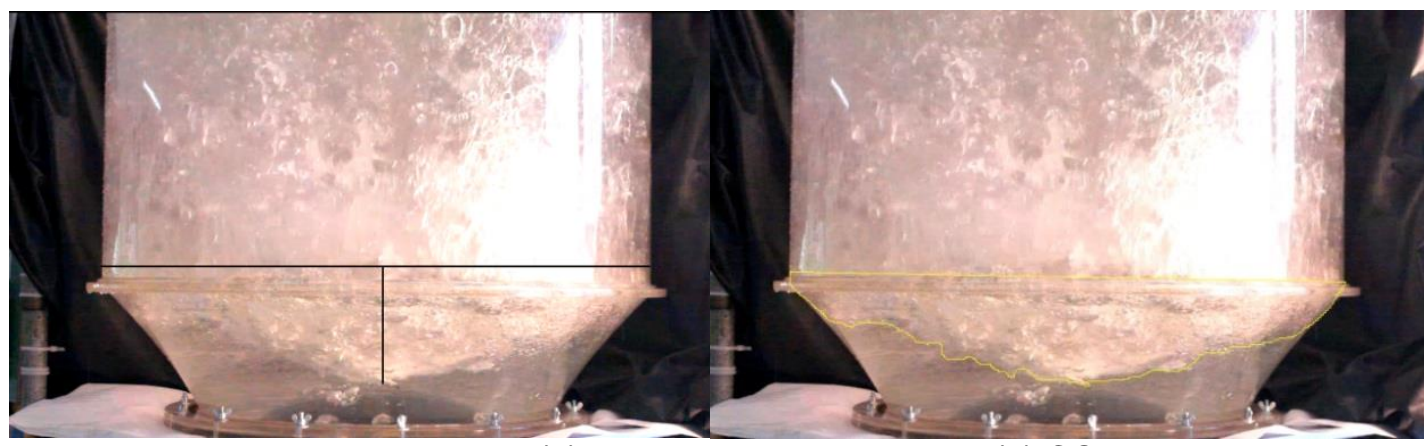

Figure 3: Jet Penetration (a) and Decarburization Area (b) CO2 desorption

The $\mathrm{CO} 2$ desorption of a caustic soda solution was used to simulate the decarburization rate at the end of the blow. The $\mathrm{pH}$ of the bath was measured after the addition of a $\mathrm{NaOH}$ solution of known concentration to give the initial $\mathrm{pH}$. A small amount of phenolphthalein was also added. $\mathrm{CO} 2$ was then injected into the bath until the $\mathrm{pH}$ reached approximately 6.5. At this point, the combined blow was initiated causing desorption of $\mathrm{CO} 2$ and an increase in the $\mathrm{pH}$ solution value. During the test, $\mathrm{pH}$ variation is recorded by a $\mathrm{pH}$ meter at predetermined time intervals until equilibrium is reached. It should be noted that the experiments were performed in triplicate.

According to Tavares et. Al. Almeida (2011), a calibration curve is used to convert pH to $\mathrm{CO} 2$ concentration in the solution, using the following relations:

$$
\begin{gathered}
\mathrm{A}=\frac{\mathrm{pH}}{\mathbf{5}} \\
\mathrm{C}_{\mathrm{CO2}}=\mathbf{3 7 2 9 4} * \mathrm{~A}^{-14.234}
\end{gathered}
$$

Where $\mathrm{A}$ is a conversion constant and $\mathbf{C}_{\mathbf{C O 2}}$ is $\mathrm{CO} 2$ concentration.

The initial concentration $\left(\mathbf{C}_{\mathbf{C O 2}}^{\mathbf{i}}\right)$, concentration at a certain time $t\left(\mathbf{C}_{\mathbf{C O 2}}^{\mathbf{t}}\right)$ and equilibrium concentration $\left(\mathbf{C}_{\mathbf{C O 2}}^{\mathbf{e q}}\right)$, obtained at the end of the experiment (when no longer observed significant variations) were used to draw the calibration curve, through the relation:

$$
-\ln \left[\frac{\mathrm{C}_{\mathrm{CO2}}^{\mathrm{t}}-\mathrm{C}_{\mathrm{CO} 2}^{\mathrm{eq}}}{\mathrm{C}_{\mathrm{CO2}}^{\mathrm{i}}-\mathrm{C}_{\mathrm{CO} 2}^{\mathrm{eq}}}\right]=\mathbf{K}_{\mathrm{tm}} * \mathbf{t}=\mathbf{G}
$$

Based on this equation it can be possible to construct a graph of linear behavior and, through the equation of the line, determine the value of $\mathbf{K}_{\mathbf{t m}}$ (mass transfer coefficient), which represents the slope of the axis.

\section{RESULTS AND DISCUSSION}

\subsection{Mixing Time - Colorimetric Analysis}

The interval between the time the addition of the tracer occurs to the point where the color of the bath becomes uniform corresponds to the mixing time. 
Tables 2 and 3 present the results of mixing time for each blowing stage, blowing flow, DBL (bath-lance distance) and the tuyeres configuration used (TBM), adding up the flow of the 12 injection points. It is noteworthy that the experiments were performed in duplicate, in order to validate the results obtained. Thus, the mixing time presented below corresponds to the average of the two values found for each experiment and their respective configuration.

Table 2: Mixing times for the decarburisation stage

\begin{tabular}{|cccccc|}
\hline Test & $\begin{array}{c}\text { Lance } \\
\text { flow rate } \\
(\mathbf{N m 3 / h )}\end{array}$ & $\begin{array}{c}\text { DBL } \\
(\mathbf{m m})\end{array}$ & $\begin{array}{c}\text { TBM flow rate } \\
\text { (NL/min) } \\
\text { Ext, Int, Central }\end{array}$ & $\begin{array}{c}\text { Mixing } \\
\text { times (s) }\end{array}$ & $\begin{array}{c}\text { Standard } \\
\text { deviation }\end{array}$ \\
\hline tkCSA 3-14 & 120 & 400 & Max, Off, Off (40) & 18.25 & 2.63 \\
\hline tkCSA 3-15 & 120 & 400 & Off, Max, Max (20) & 17.00 & 1.41 \\
\hline tkCSA 3-16 & 120 & 400 & Max, Max, Max & 17.75 & \\
\hline tkCSA 3-17 & 120 & 400 & Var, Var, Var (42) & 18.50 & 1.71 \\
\hline
\end{tabular}

Table 3: Mixing times for the final blow stage

\begin{tabular}{|cccccc} 
Test & $\begin{array}{c}\text { Lance } \\
\text { flow rate } \\
(\mathbf{N m 3 / h})\end{array}$ & $\begin{array}{c}\text { DBL } \\
(\mathbf{m m})\end{array}$ & $\begin{array}{c}\text { TBM flow rate } \\
\text { (NL/min) } \\
\text { Ext, Int, Central }\end{array}$ & $\begin{array}{c}\text { Mixing } \\
\text { times (s) }\end{array}$ & $\begin{array}{c}\text { Standard } \\
\text { deviation }\end{array}$ \\
\hline tkCSA 3-10 & 160 & 451 & Off, Max, Max (20) & 7.67 & 1.53 \\
\hline tkCSA 3-11 & 160 & 451 & $\begin{array}{c}\text { Max, Max, Max } \\
(60)\end{array}$ & 16.75 & 1.26 \\
\hline tkCSA 3-12 & 160 & 451 & Max, Off, Off (40) & 15.25 & 1.71 \\
\hline tkCSA 3-13 & 160 & 451 & Var, Var, Var (42) & 14.75 & 1.26 \\
\hline
\end{tabular}

Based on the results presented in the tables above, it is observed that the mixing times for the final blow step $\left(160 \mathrm{Nm}^{3} / \mathrm{h}\right)$ were lower than the times recorded in the decarburization stage $\left(120 \mathrm{Nm}^{3} / \mathrm{h}\right)$. The results obtained may be related to the fact that the lance flow exerts a predominant effect on the progression of the mixture when compared to the DBL and TBM configuration and flow. Comparing the tests in which the same TBM configurations were used, with different lance flow rates, we can observe some similarities. The tkCSA tests 3-10 and 315 (Off, Max, Max - $20 \mathrm{NL} / \mathrm{min}$ ), for example, showed the lowest mixing times of the final blow and decarburization moments, respectively. From the analysis of the initial behavior of these tests it is possible to notice that, when injected, the tracer moves to the center of the converter and then undergoes influence of a barrier created by the activated internal tuyeres. However, due to the higher lance flow rate of $3-10\left(160 \mathrm{Nm}^{3} / \mathrm{h}\right)$, the tracer, upon coming in contact with the combined blow, spreads more vigorously than in the tkCSA 3-15 $\left(120 \mathrm{Nm}^{3} / \mathrm{h}\right)$, where the tracer tends to follow by the outer crown of the acrylic.

(Figure 4) illustrates the behavior of the tracer during the combined blow for two experiments with similar lance flow rate $\left(160 \mathrm{Nm}^{3} / \mathrm{h}\right)$, tkCSA 3-10 (20NL / min) and 3-11 (60NL / min) at three different time points $(25 \%, 50 \%$ and $75 \%)$. 


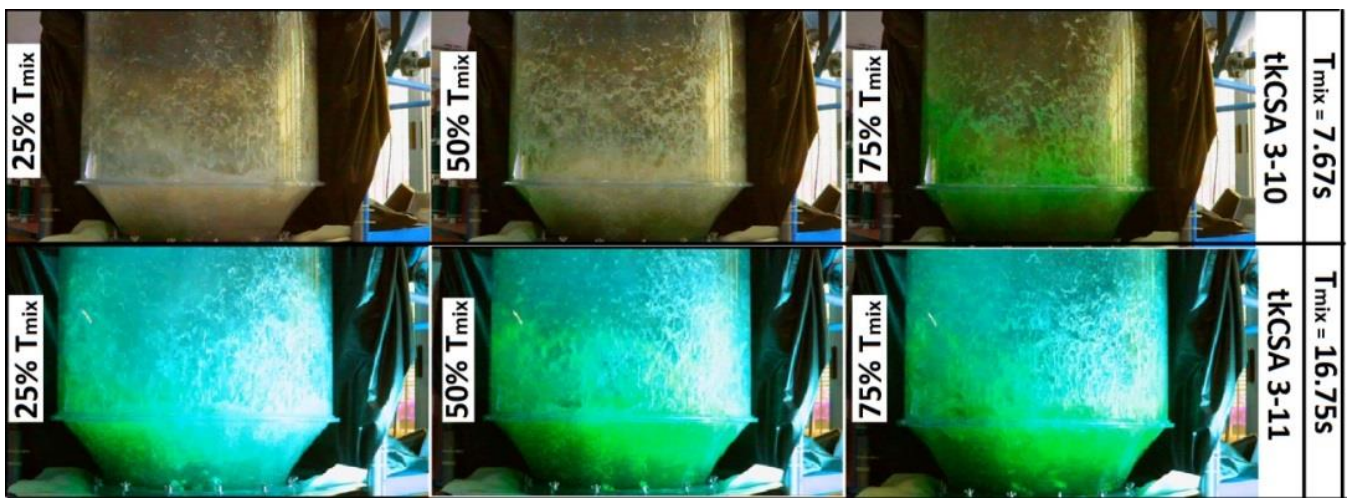

Figure 4: Comparison of tracer behavior

It is important to mention that for industrial practice the greatest interest is that there is rapid homogenization of the bath, even if it is not totally mixed. Thus, the configuration of the tkCSA test 3-10 (20NL / $\mathrm{min}$ ) may be more interesting for the post-stirring practice, since for $75 \%$ of the mixing time (Tmix) the tracer has been practically taken. In addition, this TBM flow rate is low in relation to the others, causing reduction of inert gas consumption and, therefore, less wear of the refractory, reducing the costs of the process.

\subsection{Jet Penetration and Decarburization Area}

Tables 4 and 5 relate the decarburization area and penetration results for each blow stage, the $\mathrm{DBL}$ and the tuyeres configuration used in each experiment.

Table 4: Values of decarburisation area and jet penetration to decarburization stage

\begin{tabular}{|cccccc}
\hline Experimento & $\begin{array}{c}\text { LaSiP } \\
\text { DBL } \\
(\mathbf{m m})\end{array}$ & $\begin{array}{c}\text { LaSiP } \\
\text { Flow } \\
\text { rate } \\
(\mathbf{N m 3 / h})\end{array}$ & $\begin{array}{c}\text { Tuyeres } \\
\text { configurations } \\
\text { (NL/min) }\end{array}$ & $\begin{array}{c}\text { Decarburization } \\
\text { area (\%) }\end{array}$ & $\begin{array}{c}\text { Jet } \\
\text { penetration } \\
(\mathbf{m m})\end{array}$ \\
\hline tkCSA 3-14 & 400 & 120 & Max, Off, Off (40) & 60.42 & 136.66 \\
\hline tkCSA 3-15 & 400 & 120 & Off, Max, Max (20) & 60.45 & 140.64 \\
\hline tkCSA 3-16 & 400 & 120 & Max, Max, Max (60) & 57.89 & 134.73 \\
\hline tkCSA 3-17 & 400 & 120 & Var, $\operatorname{Var}, \operatorname{Var}(42)$ & 61.34 & 139.35 \\
\hline
\end{tabular}

Table 5: Values of decarburization area and jet penetration to decarburization stage

\begin{tabular}{|cccccc}
\hline Experimento & $\begin{array}{c}\text { LaSiP } \\
\text { DBL } \\
(\mathbf{m m})\end{array}$ & $\begin{array}{c}\text { LaSiP } \\
\text { Flow } \\
\text { rate } \\
(\mathbf{N m 3 / h})\end{array}$ & $\begin{array}{c}\text { Tuyeres } \\
\text { configurations } \\
\text { (NL/min) }\end{array}$ & $\begin{array}{c}\text { Decarburization } \\
\text { area (\%) }\end{array}$ & $\begin{array}{c}\text { Jet } \\
\text { penetration } \\
(\mathbf{m m})\end{array}$ \\
\hline tkCSA 3-10 & 451 & 160 & Off, Max, Max (20) & 66.71 & 126.46 \\
\hline tkCSA 3-11 & 451 & 160 & Max, Max, Max (60) & 69.87 & 133.17 \\
\hline tkCSA 3-12 & 451 & 160 & Max, Off, Off (40) & 64.44 & 124.51 \\
\hline tkCSA 3-13 & 451 & 160 & Var, Var, Var (42) & 66.98 & 128.58 \\
\hline
\end{tabular}


Taking into account the data recorded in the tables 4 and 5 , it can be noticed that the highest values of penetration were obtained in the tests that used lance flow rate equal to $120 \mathrm{Nm}^{3} / \mathrm{h}$ and $\mathrm{DBL} 400 \mathrm{~mm}$, when compared to the values measured in the tests with lance flow equal to $160 \mathrm{Nm}^{3} / \mathrm{h}$ and DBL $451 \mathrm{~mm}$. On the other hand, it was observed that the highest values for decarburisation area were found in the tests performed with higher lance flow $\left(160 \mathrm{Nm}^{3} / \mathrm{h}\right)$ and DBL $(451 \mathrm{~mm})$. This behavior can be illustrated in (Figure 3), where two simulated tests with different operating conditions are compared.

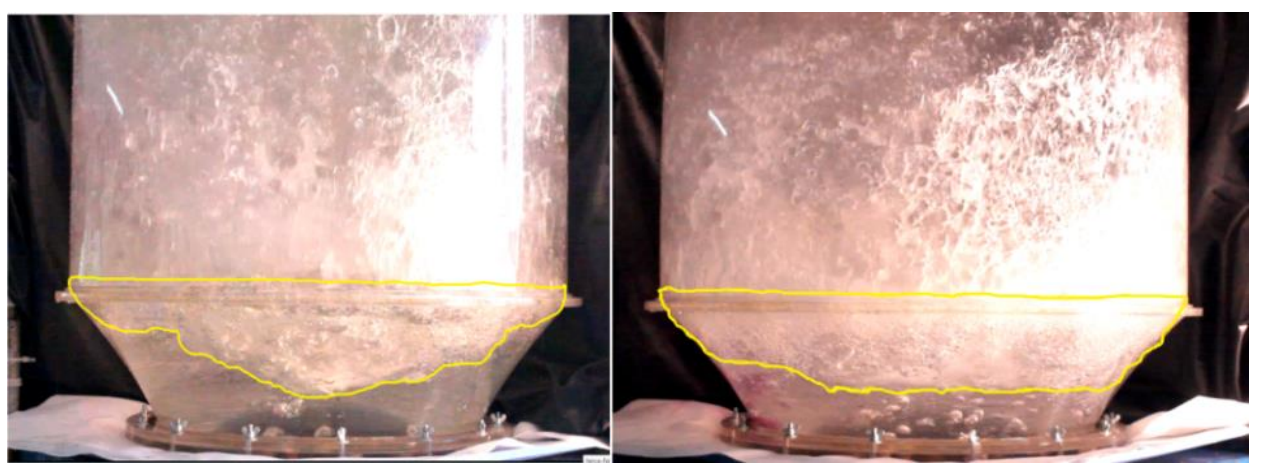

Figure 5: Comparison of Decarburization area and Jet Penetration: (a) tkCSA 3-15- DBL $400 \mathrm{~mm}$ and $120 \mathrm{Nm}^{3} / \mathrm{h}$ (b) tkCSA $3-13-\mathrm{DBL} 451 \mathrm{~mm}$ and $160 \mathrm{Nm}^{3} / \mathrm{h}$.

By analyzing (Figure 5) and knowing that the demarcated area signals the aspect of the decarburization area and the reach of the jet penetration, some differences are observed. In letter (a) it can be observed that the jet, because the DBL is smaller, cannot reach a large area of spreading. This leads to smaller decarburization areas and larger jet penetrations.

In the case of letter (b), is characterized a test in which the presence of dead zones in the sides of the acrylic is minimized by the amplitude of reach of the jet. Since the DBL and the flow rate are larger in this case, the jet interacts, on impact, with a larger bath area that offers superior resistance to penetration, increasing the amount of bubbles and the water-gas contact surface area (MAIA , 2007). Thus, the configuration of tests with top flow rate $160 \mathrm{Nm}^{3} / \mathrm{h}$ may be more suitable for dephosphoration in primary refining and potentially may represent an attack on the trunnion line. (Figure 6) schematically depicts the location of jet impact in both cases.
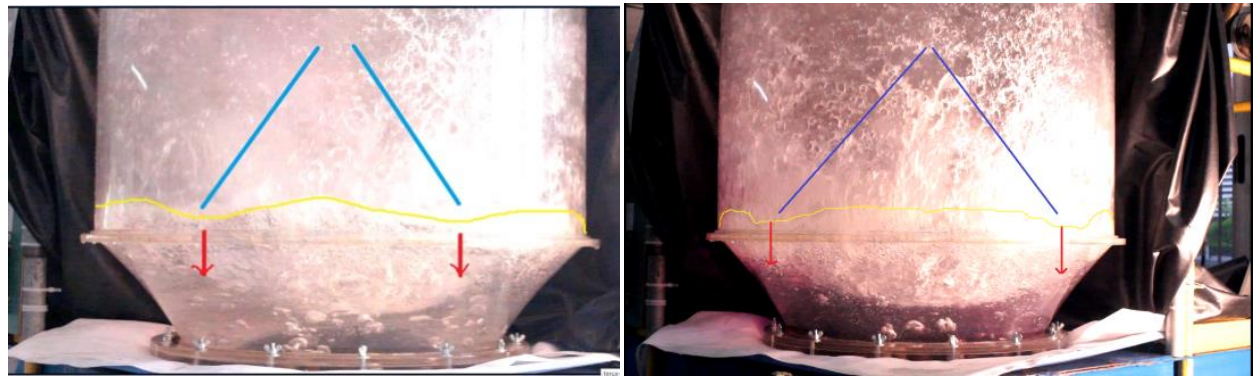

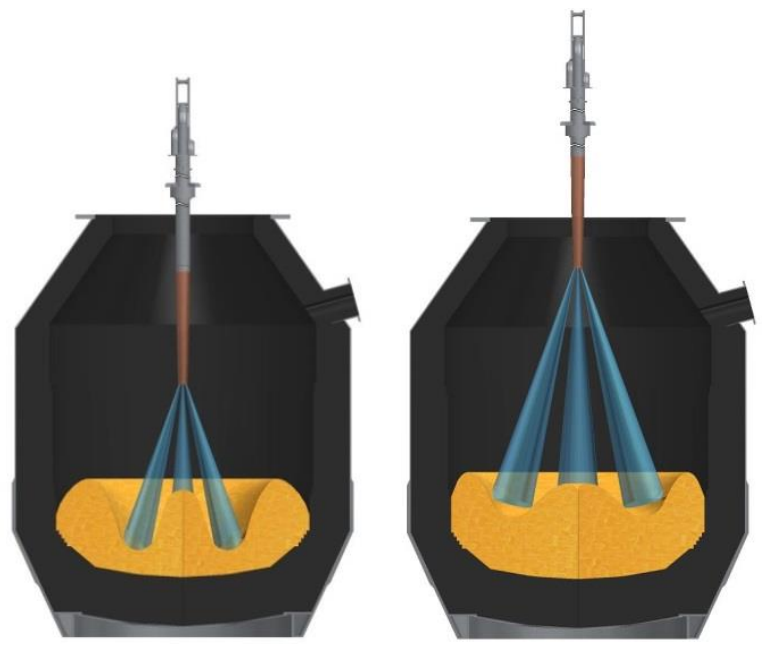

Figure 6: Jet impact location

By means of an analysis focused on the influence of the tuyeres on the jet penetration and the decarburization area, it is possible to observe in the tests related to the final blow step (160 $\mathrm{Nm}^{3} / \mathrm{h}$ ) an interesting behavior of the experiments in which the external radius were connected. Due to the greater jet range in the lateral parts of the acrylic caused by the higher DBL in these tests, a hypothesis is generated of a possible impact between the jet and the bubble pen coming from the external radius tuyeres, causing a reduction in the size of the decarburization area and jet penetration. This hypothesis is illustrated by the fact that the lower values of jet penetration and decarburization area are related to the tkCSA test 3-12, in which only the external radius tuyeres were in operation. In addition, it is worth mentioning that the results found for the tkCSA 3-10 test (internal and central radius driven) were higher than those of tkCSA 3-12, leading to a probable preponderance of internal and central radius tuyeres in relation to the external radius ones and, therefore, optimizing the process economy, since the consumption of injected gas is significantly lower.

In the case of tests related to decarburizing step (DBL $400 \mathrm{~mm}$ ), it was observed that the values of decarburization area were very similar. This similarity of results leads to a probable analysis that the tuyeres did not represent significant influence in the experiments in front of the flow rate of the jet. Thus, with regard to process economics, the configuration used in the tkCSA 3-15 test, where the flow rate of the tuyeres is minimal and the results for area of decarburization and jet penetration are satisfactory, is highlighted.

\subsection{CO2 desorption}

The aim of desorption is to represent the rate of decarburization in refining processes, especially in the final stages, when the reactions occur through diffusion of the gas in the medium. (Figure 7) shows the behavior obtained for two experiments: 


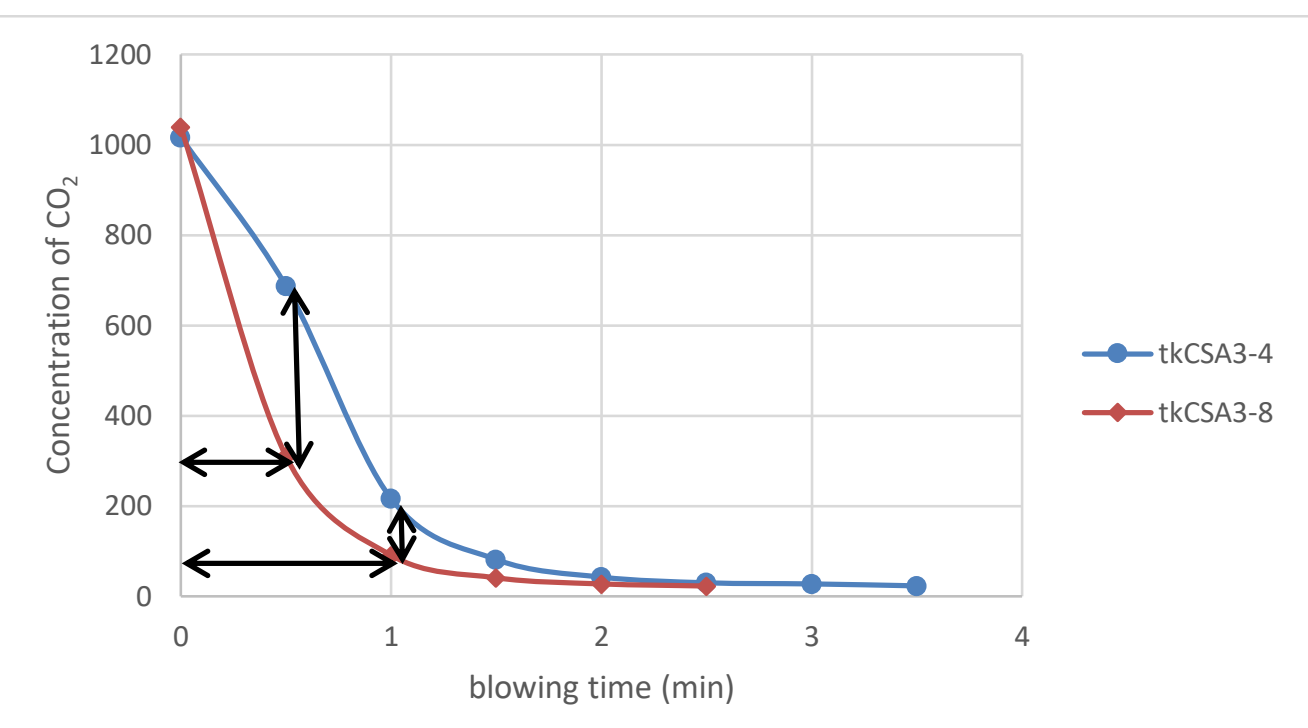

Figure 7: CO2 Concentration x Blowing Time

From the figure 7 , it is possible to note that the decay rate of the $\mathrm{CO} 2$ concentration was more pronounced for the 3-8 tkCSA experiment. This fact can be justified because its total blowing flow $\left(162.52 \mathrm{Nm}^{3} / \mathrm{h}\right)$ is higher than that of the tkCSA 3-4 experiment $\left(121.2 \mathrm{Nm}^{3} / \mathrm{h}\right)$. The upper flow is responsible for causing a greater mass movement, which favors the kinetics of the reactions. Thus, it is recommended in industrial practice an increase in the flow rate, in order to intensify the decarburization.

Considering the values of $\mathrm{pH}$ and [CO2] during the blow, a first-order kinetic equation was generated, so that the slope of the line represents the mass transfer constant Ktm, as shown in (Figure 8).

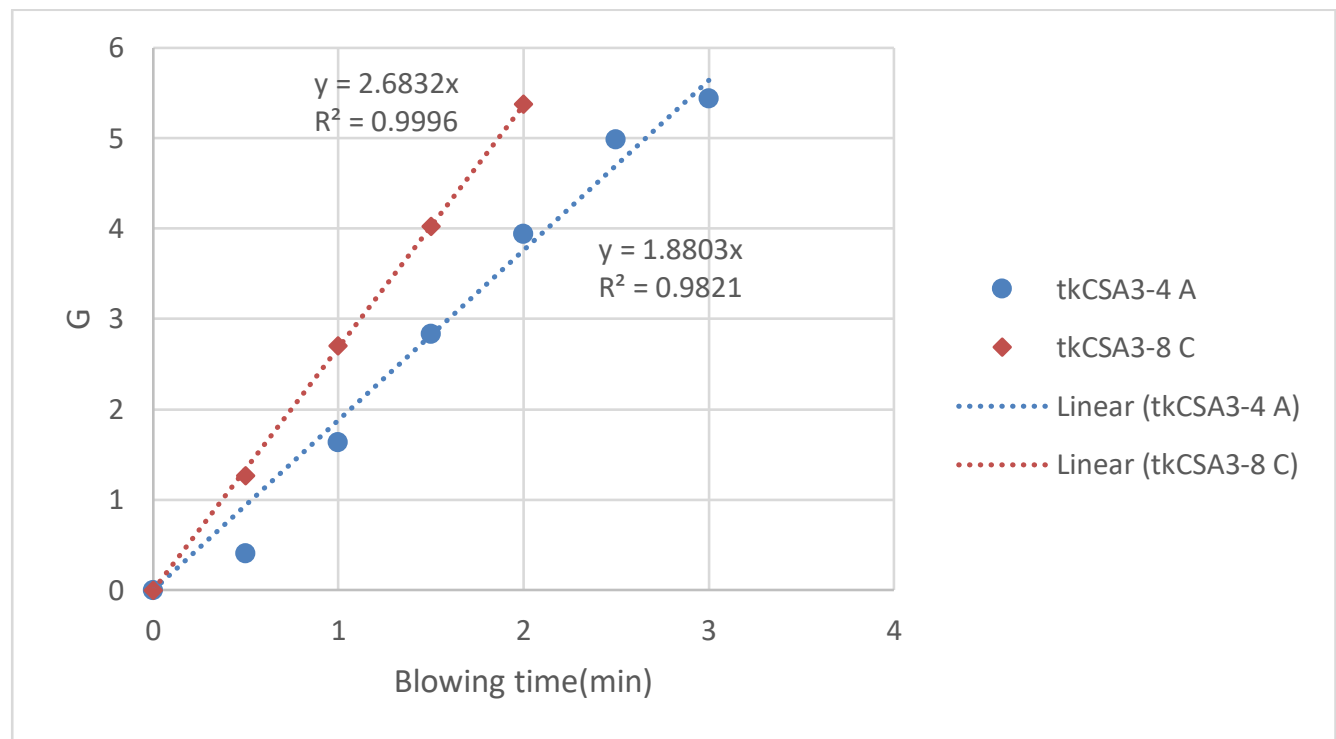

Figure 8: $\mathrm{G} \times$ Blowing time

Considering the slope presented by the graph in each experiment, it was possible to obtain the values of "Ktm" for each configuration analyzed. It is noteworthy that the experiments were performed in triplicate.

The mean Ktm values and the respective standard deviations are shown in (Table 6). 
Table 6: Mean Ktm values for each experiment

Test

$\begin{array}{lll}\text { Lance flow } & \text { TBM flow } \\ \text { rate }\left(\mathrm{Nm}^{3} / \mathrm{h}\right) & \begin{array}{l}\text { Total flow Mean } \mathrm{Ktm} \\ \text { rate } \\ (\mathrm{NL} / \mathrm{min})\end{array} & \\ & & \end{array}$

Standard

deviation

\begin{tabular}{llllll} 
tkCSA 3-9 & 160 & 42 & 162.52 & 2.460 & 0.149 \\
\hline tkCSA 3-8 & 160 & 20 & 161.2 & 2.425 & 0.222 \\
\hline tkCSA 3-7 & 160 & 60 & 163.6 & 2.568 & 0.166 \\
\hline tkCSA 3-2 & 160 & 40 & 162.4 & 2.349 & 0.160 \\
\hline tkCSA 3-3 & 120 & 40 & 122.4 & 1.977 & 0.242 \\
\hline tkCSA 3-4 & 120 & 20 & 121.2 & 1.902 & 0.025 \\
\hline tkCSA 3-5 & 120 & 60 & 123.6 & 1.849 & 0.234 \\
\hline tkCSA 3-6 & 120 & 42 & 122.52 & 1.934 & 0.157
\end{tabular}

From the values recorded in the table above it is possible to notice that the experiments with lance flow rate of $160 \mathrm{Nm}^{3} / \mathrm{h}$ showed higher values of $\mathrm{Ktm}$ when compared to those registered by the tests that used a flow rate of $120 \mathrm{Nm}^{3} / \mathrm{h}$. In this way, the tests with greater lance discharge showed an increase in the mass displacement of the bath, favoring the last stage of decarburization. In view of these results, it is evident the greater influence of the blow by the top on the mass transfer, as can be seen when comparing the $\mathrm{Ktm}$ values obtained in the tests tkCSA 3-3 and tkCSA 3-5, which, despite having a lower TBM flow, presented a higher value for the constant Ktm.

In addition, it is worth mentioning the behavior presented by the tkCSA 3-8 and tkCSA3-4 experiments, both with configuration of the tuyeres with a flow rate of $20 \mathrm{NL} / \mathrm{min}$. When analyzing the values of the mass transfer constant of these experiments, it is observed that these values are quite equivalent to the values of other experiments that used higher flow rates. For example, the tkCSA 3-8 experiment had a mass transfer constant greater than that of the tkCSA 3-2 experiment, both simulating the blow end. However, the TBM outflow from experiment 3-2 is twice as high as the flow from experiment 3-8. This is an economically important point, since the lower the flow used, the lower the operating costs. In the case of simulation of decarburization, experiment 3-4 (flow TBM $20 \mathrm{NL} / \mathrm{min}$ ) presented higher value of the mass transfer constant than experiment 3-5 (flow TBM $60 \mathrm{NL} / \mathrm{min}$ ). Therefore, with a lower flow rate and, consequently, lower costs, satisfactory results were obtained.

By means of an analysis focused on the influence of the tuyeres (TBM) in the CO2 desorption process, no relation was observed between the total flow rate and the value of the mass transfer constant. In contrast, it can be seen that the configuration of the tuyeres has a significant importance in the value of $\mathrm{Ktm}$. In the case of the tests of the end of the blowing stage, it was observed that the internal radius and the central tuyeres present greater influence on the $\mathrm{Ktm}$ value. This fact can be highlighted by comparing the tkCSA 3-9, tkCSA 3-8 and tkCSA 3-7 tests in relation to the tkCSA 3-2 experiment, in which only the external tuyeres were activated. It was observed that the highest values of Ktm were reached by the tests in which the internal and central radius tuyeres were used. It is worth noting the tkCSA 3-8 test (external radius off), in which the mass transfer constant obtained was higher than the Ktm of the tkCSA 3-2 experiment (internal and central radius off).

On the other hand, the experiments of the decarburization stage presented different behaviors. One possible explanation concerns on the different bath-lance distances. With the decrease of DBL, the jet reaches a smaller surface area of the bath (impacting predominantly the central region), which can interfere negatively in the action of the internal and central radius tuyeres. 
This can be demonstrated by the fact that the largest mass transfer constant was obtained for the tkCSA 3-3 test, in which only the outer radius tuyeres were connected.

Another approach refers to the comparison between the mass transfer constant and the decarburization area, which can be illustrated by (Figure 9 ).

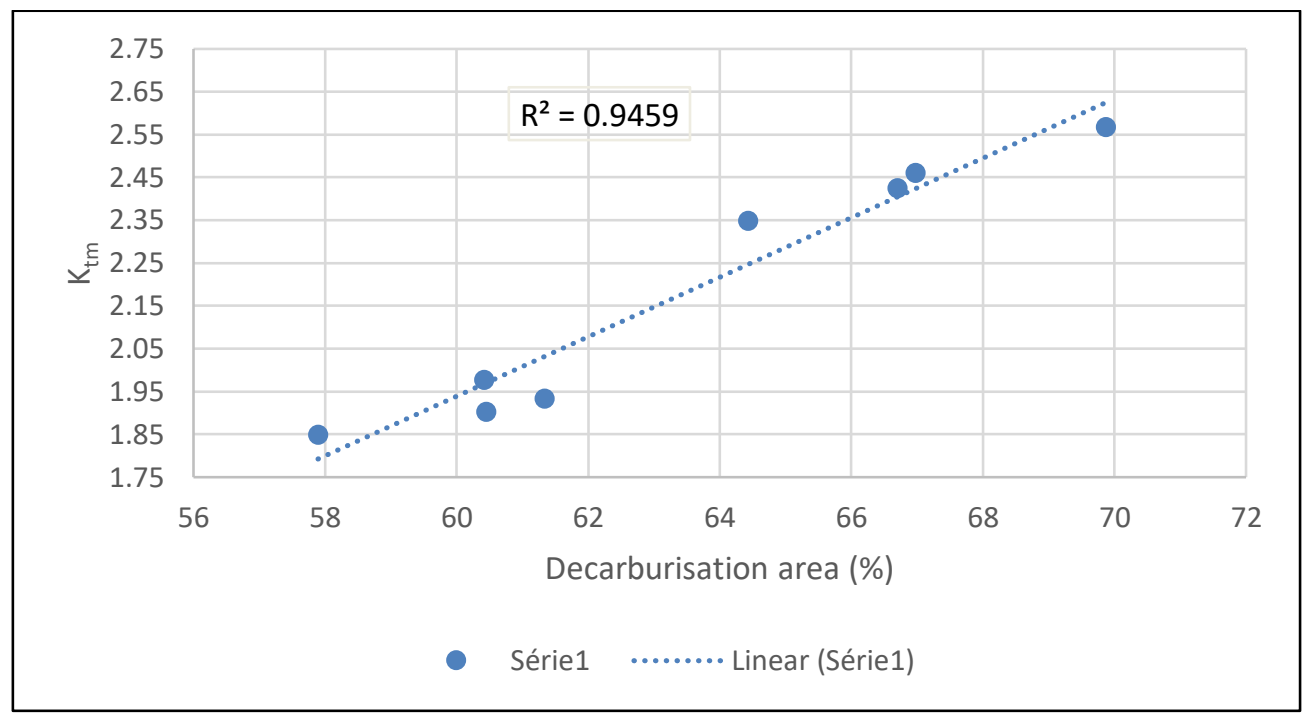

Figure 9: $\mathrm{K}_{\mathrm{tm}} \times$ decarburization area

By analyzing the graph above, it is possible to verify that the larger the decarburization area, the greater the mass transfer constant. This relationship can be explained by the increase in the probability of occurrence of chemical reactions when raising the decarburization area.

\section{CONCLUSION}

From the various means of analysis used during the experiments, the following conclusions were obtained:

1. The lance flow rate is predominant in determining the homogenization of the bath compared to the other parameters. In relation to the TBM, the experiments with configuration of external radius off and the internal radius connected to the maximum flow rate showed the lowest mixing times for the two simulated stages (decarburization and final blow).

2. For a higher lance flow rate, the jet reaches a longer range along the acrylic, which allows a clash between the jet and the bubble lance from the external radius, causing a reduction in the size of the decarburization area and penetration. The highest values for the basin were obtained in the experiments with higher lance and DBL.

3. Superior lance flow rates are responsible for a greater mass movement, which favors the kinetics of the reactions. In relation to the TBM, the configuration of internal radius tuyeres and the central one operated at maximum flow had a greater influence on the value of $\mathrm{Ktm}$ in relation to those of connected external radius. However, for lower values of DBL the Ktm is higher when the external ones are activated, since the jet interferes negatively in the action of the central and internal tuyeres.

4. It was verified that the largest values of the mass transfer constant correspond to the experiments with the largest decarburization area, which validates the theory that larger impacted areas allow the greater occurrence of chemical reactions. 
5. The results obtained for $\mathrm{DBL} 0.400 \mathrm{~m}$ show that the tuyeres, regardless of the configuration, have a lower influence on the decarburization area and the penetration when compared to the results for DBL $0.451 \mathrm{~m}$. This represents an opportunity to optimize operations by using the minimum settings in TBM.

6. All the analyzes concluded above lead to a possible hypothesis that the best configuration of tuyeres would be the one with external tuyeres off and the central and internal ones operated at the maximum flow rate $(20 \mathrm{NL} / \mathrm{min})$. This configuration has benefits for the industrial process, since it allows to achieve good metallurgical results using minimum flow of TBM, reducing the operational costs from the saving in consumption of inert gas and, consequently, the wear of the refractory.

\section{ACKNOWLEDGMENTS}

The authors thank the Universidade Federal de Minas Gerais for providing the dependencies of Process Simulation Laboratory - LaSiP and the inputs for the tests. They also thank thyssenkrupp CSA and Lumar Metals by encouraging continued research and support.

\section{REFERENCES}

1 1. ALMEIDA, L. P. et al. Effects of some operational parameters upon degaseification rate, mixing time, splashing and skull development in a combined-blow converter during steelmaking refining: a physical model approach. In: AISTEch 2010 -THE IRON \& STEEL TECHNOLOGY CONFERENCE AND EXPOSITION, 2010, Pittsburgh. Proceedings... Warrendale, PA: AIST, 2010. p. 274-85.

2 2. MAIA, B. T. Modelamento Físico e Matemático do Escoamento de Fluidos no interior de convertedores básicos a oxigênio e no processo EOF- Avaliação de diferentes configurações de lanças para injeção de oxigênio. Belo Horizonte: Escola de Engenharia da Universidade Federal de Minas Gerais, 2013. (Dissertação, Doutorado em Engenharia Metalúrgica).

3 3. MAiA, B. T. FAUSTINO, R. A., ABREU, G., COSTA, B., TAVARES, R. P., Efeitos dos Parâmetros de Sopro no Tempo de Mistura Utilizando Modelo Físico de Convertedor. Anais do

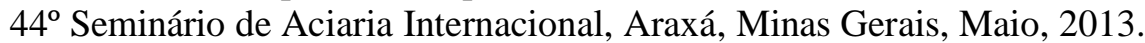

4 4. MAIA, B. T., PETRUCELli, A. C., DINIZ, C. N. A., SILVEIRA, D., ANDRADE, P. H. M. S., IMAGAWA, R. K., TAVARES, R. P., Comparação da Penetração do sopro de Oxigênio em Convertedores BOF com Bicos Multifuros utilizando Modelagem Física. Seminário de Aciaria Internacional. Porto Alegre, Maio 2014.

5 SeShadri, V., TAVARES, R. P., SILVA, C. A., SILVA, I. A. Fenômenos de Transporte: Fundamentos e aplicações nas Engenharias Metalúrgicas e de Materiais. São Paulo: Associação Brasileira de Metalurgia, Materiais e Mineração, 2010. 812p.

6 5. SZEKELY, J. THEMELIS, N. J., Rate Phenomena in Process Metallurgy. 1 ed. Montreal: John Wiley \& Sons, 1971. 784p.

7 6. TAVARES, R. P. "Mass Transfer in Steelmaking Operations". Belo Horizonte: Escola de Engenharia da Universidade Federal de Minas Gerais, 2011. 